
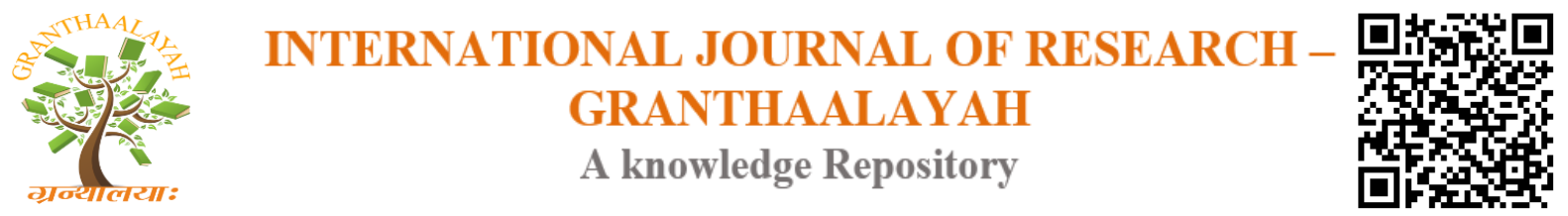

Management

\title{
AWARENESS AND ATTITUDES OF CONSUMERS IN USING INTERNET FOR ONLINE PURCHASE
}

\author{
R. Anantha Laxmi $*^{1}$, K. Arun Sarath Kumar ${ }^{2}$ \\ ${ }^{* 1}$ PhD Research Scholar, PG and Research Department of Commerce, V.O. Chidambaram \\ College, Thoothukudi, INDIA \\ 2 Alumnus, PG and Research Department of Commerce, V.O. Chidambaram College, \\ Thoothukudi, INDIA
}

DOI: https://doi.org/10.29121/granthaalayah.v4.i9(SE).2016.2507

\begin{abstract}
Online shopping behavior (also called online buying behavior and Internet shopping or buying behavior) refers to the process of purchasing products or services via the Internet. $E$ commerce has been growing very fast because of many advantages associated with buying on internet because of lower transaction and search cost as compared to other types of shopping. Through online shopping consumers can buy faster, more alternatives and can order product and services with comparative lowest price. Therefore, in this paper, the researchers have carefully analyzed the consumers' attitude and behavior towards online shopping. This paper gives a comprehensive picture of the awareness and attitudes of consumers in using internet for online purchase. A sample size of one hundred and five respondents is selected for the research from Thoothukudi district. The study quantitatively analyses the awareness of consumers in using internet, attitudes and behaviors of the consumers in buying various products from internet, hours of using the internet and the like using primary data. Appropriate findings and suggestions are given in the paper.
\end{abstract}

Keywords:

Online shopping, buying behavior, online purchase.

Cite This Article: R. Anantha Laxmi, and K. Arun Sarath Kumar, "AWARENESS AND ATTITUDES OF CONSUMERS IN USING INTERNET FOR ONLINE PURCHASE", International Journal of Research - Granthaalayah, Vol. 4, No. 9: SE (2016): 26-36.

\section{INTRODUCTION}

E-Commerce is the buying and selling of goods and services on the internet, especially the World Wild Web. Online shopping is a form of E-commerce whereby consumers directly buy goods or services from a seller over the internet. It is done through an online shop, e-shop, estore, internet shop or online store. All the products in online stores are described through text, 
with photos and with multimedia files. Many online stores provide links for extra information about their products (Saad Akbar and Paul TJ James). Most consumers form expectations of the product, vendor, service, and quality of the website that they patronize before engaging in online shopping activities. These expectations influence their attitudes and intentions to shop at a certain Internet store, and consequently their decision-making processes and purchasing behavior. If expectations are met, customers achieve a high degree of satisfaction, which influences their online shopping attitudes, intentions, decisions, and purchasing activity positively. In contrast, dissatisfaction is negatively associated with these four variables (Jahng et al., 2001).

Education plays a moderating role in the relationship between the three basic determinants and consumers' attitude towards online shopping. Higher educated consumers are more comfortable using non-store channels, like the internet to shop. Further, consumers with higher household incomes intent to shop more online compared to lower income consumers. A reason for this is that higher household incomes are often positively correlated with possession of computers, internet access and higher education levels of consumers.

\section{STATEMENT OF PROBLEM}

Online shopping in India has grown 128 percent in 2012-2013 compared to only 40 percent the previous year 2011-2012 according to Google Online Shopping Growth in India - 2013. Indians like the idea of shopping through the Internet as reported by Google India trends. From the reports of Google India trends in 2012, it has been stated that 2013 be a strong growth year for categories like apparels, accessories, baby products, home furnishings, and health nutrition. And this growth is expected to come from outside of the top eight metro cities in India (Hemamalini.K., 2013). A few years ago, consumers purchased clothes from malls, books from bookstores, traded stock through brokers. With the emergence of Internet and Online shopping, businesses are coming to our doorstep.

The main purpose of this study is to understand the factors that influence consumer's attitude and behaviors towards online shopping. How consumers form such attitudes is also focused on by the researchers with the help of true online shoppers. Now a days all the goods are available in local market. However the consumers prefer to buy goods online. Hence, the researchers have made an attempt to find out the reasons for buying goods online instead of physical purchase in a local market.

\section{RESEARCH OBJECTIVES}

The following are the objectives of the study

1) To analyze the awareness and attitudes of consumers in operating internet for online purchase.

2) To understand the consumers' attitude towards online shopping from the products they purchase using internet.

3) To investigate how socio-demographic factors (age and monthly income) affect consumers' attitude towards online shopping. 


\section{HYPOTHESES}

The following are the null hypotheses to be tested in the study $\mathrm{H}_{0}$ 1: Age and income do not influence the products purchased through online shopping. $\mathrm{H}_{0}$ 2: Price of the product purchased through online shopping does not depend on its availability, advertisement and transportation charges.

\section{SIGNIFICANCE OF THE STUDY}

The following are the significance of the study

1) This study helps to find out the awareness and attitudes of consumers in operating internet for online purchase.

2) The present study provides a reliable and clear perspective for describing and evaluating the attitudes of consumers.

3) This study helps to identify the concept of online shopping and its advantages in promoting consumer friendliness.

\section{SCOPE OF THE STUDY}

The present study covers the Thoothukudi district of Tamil Nadu. It deals with awareness and attitudes of consumers in buying goods online. The period of this study is about one year (i.e.) from June 2014 to May 2015.

\section{METHODOLOGY}

\subsection{RESEARCH DESIGN}

Since the present study has its own predetermined objectives and methodology, it is both descriptive and analytical in nature. The study has made an attempt to explain the consumer awareness and attitudes of consumers in buying goods online.

\subsection{SAMPLING DESIGN}

By adopting random sampling method respondents were selected from various parts of Thoothukudi district. The sample size of this study is 105. Structured interview schedule was used to collect the relevant data among the consumers in Thoothukudi District.

\subsection{SOURCE OF DATA}

The present study is based on both primary data and secondary data. Primary data were collected through interview schedules. Secondary data were collected through books, websites, articles, journals and newspapers. 


\subsection{FRAMEWORK OF ANALYSIS}

Statistical package for the Social Science (SPSS) software package version 20 is used to analyze the data. The tools include Bar chart, Pie chart, Chi-square Analysis, Kruskal-Wallis test, Rank test and Multiple Regression.

\section{RESULTS AND DISCUSSION}

In the study, frequency infers the respondents' products purchased in 6 months and mode of payment using bar chart and pie chart respectively. Chi-square Analysis has been used to analyze the relationship between the profile of the respondents and their attitude in purchasing goods online. Kruskal-Wallis test has been used to find out the relationship between the age of the respondents and the goods purchased by them online. Multiple regression analysis has been used to find out the influence of advertisement, availability and transportation charges on the price of the product.

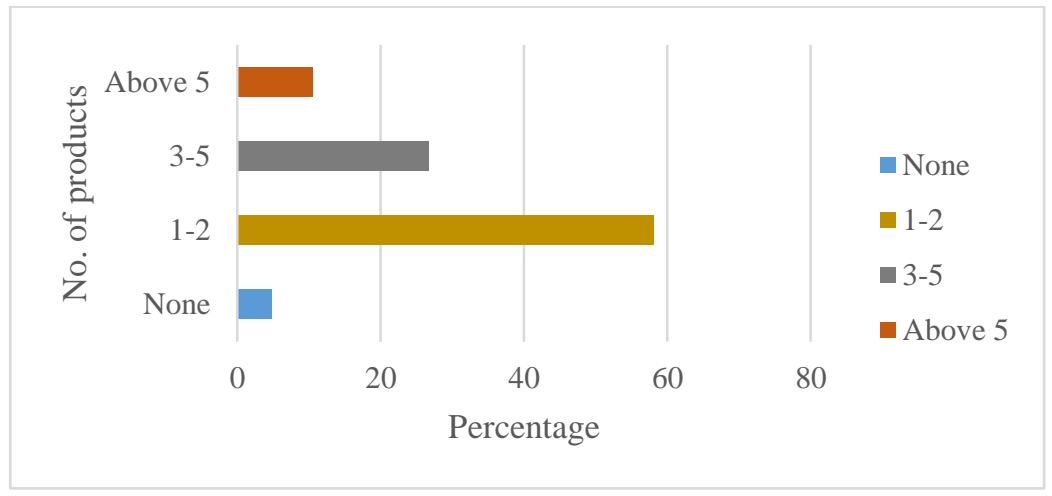

Source: Primary Data

Figure 1: Product purchased in past 6 months

Figure 1 reveals the number of products purchased by the consumers in the past 6 months. 58.1 per cent of the respondents purchased 1-2 products in the past 6 months, 26.7 per centof the respondents purchased 3-5 products, 10.5 per cent of the respondents purchased above 5 products and the remaining 4.8 per cent of the respondents did not purchase any product. Therefore, majority of the respondents purchased 1-2 products in the past 6 months through online shopping.

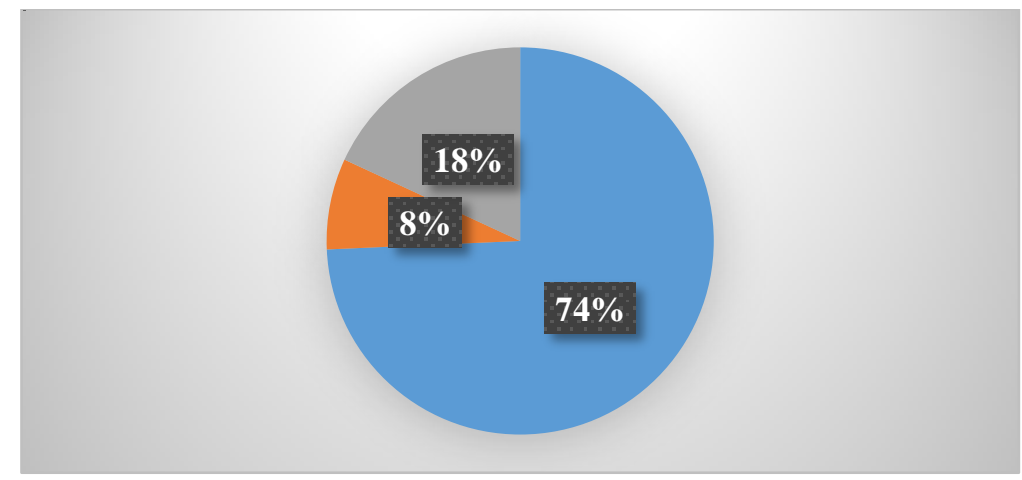

Figure 2: Mode of payment

Source: Primary Data 
Figure 2 reveals the mode of payment preferred by the respondents. 74 per cent of the respondents prefer cash payment, 18 per centof the respondents prefer debit card payment, and remaining 8 per cent of the respondents prefer credit card payment. Therefore, majority of the respondents purchasing goods online prefer cash payment.

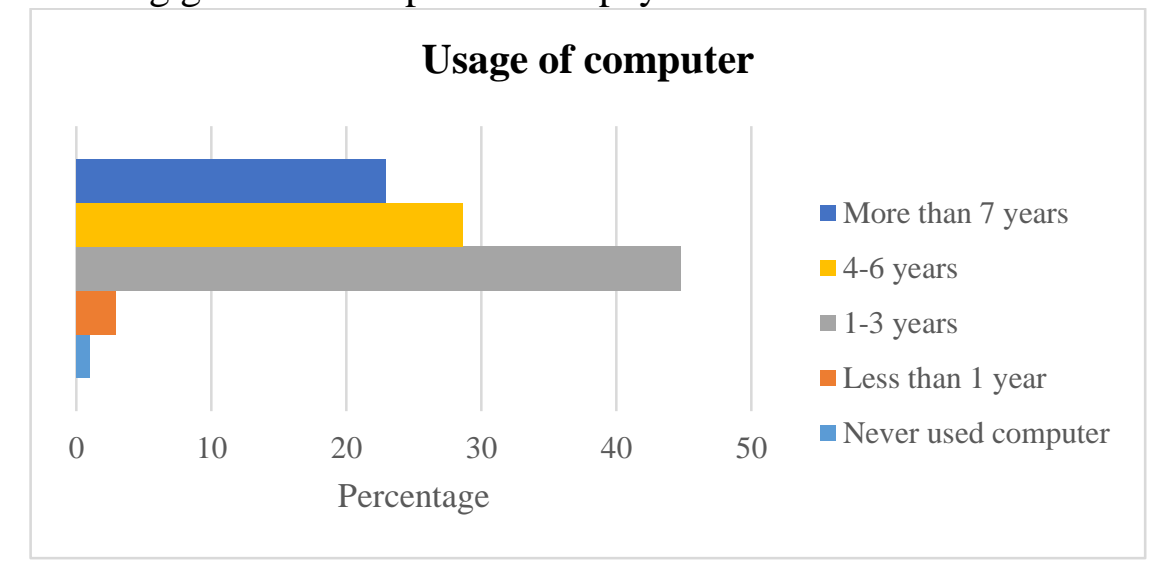

Source: Primary Data

Figure 3: Usage of computer

Figure 3 shows the usage of computer by the respondents. 44.8 per cent of the respondents use computer for 1-3 years, 28.6 per centof the respondents for4-6 years, 22.9 per cent of the respondents for more than 7 years, 2.9 per cent of the respondents for less than a year and remaining 1 per cent of the respondents have never used computer. Therefore, majority of the respondents purchasing goods online use computer for 1-3 years.

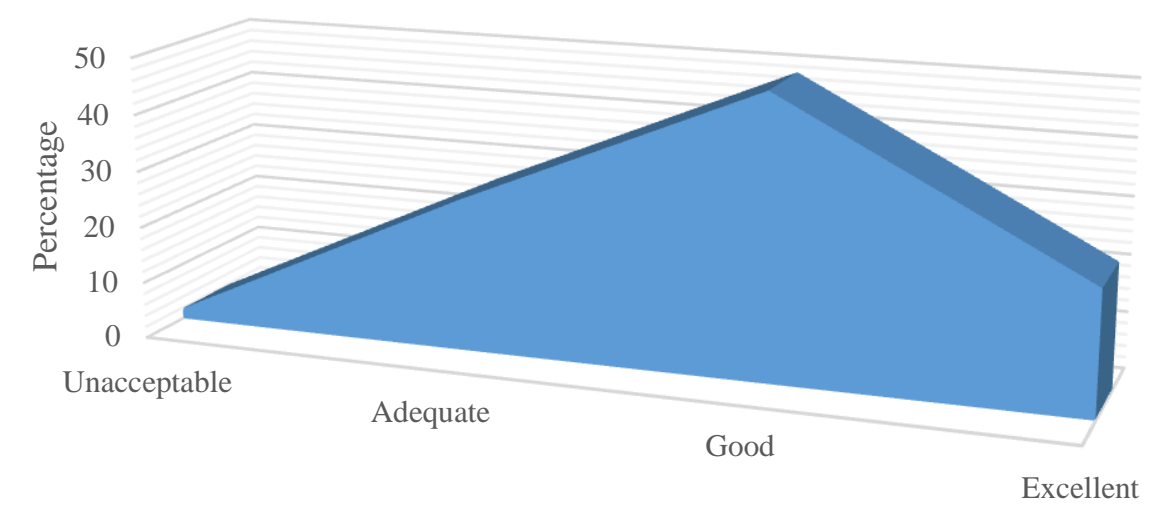

\section{Source: Primary Data}

Figure 4: Overall quality of products and services online

Figure 4 discloses the overall quality of products and services online. 49.5 per cent of the respondents rate good, 26.7 per cent of the respondents rate adequate, 21.9 per cent of the respondents rate excellent, remaining 1.9 per cent of the respondents rate unacceptable. Therefore, majority of respondents purchasing goods online rate the overall quality as good. 
Table 1: Crosstab on Age and Product purchased in past 6 months

\begin{tabular}{|c|c|c|c|c|c|c|}
\hline \multirow{2}{*}{ Age } & & \multicolumn{4}{|c|}{ Product purchased in past 6 months } & \multirow{2}{*}{ Total } \\
\hline & & None & 1-2 & 3-5 & Above 5 & \\
\hline \multirow{3}{*}{$\begin{array}{ll}\text { Below } & 20 \\
\text { years } & \end{array}$} & Respondents & 0 & 12 & 4 & 1 & 17 \\
\hline & Age & $0.0 \%$ & $70.6 \%$ & $23.5 \%$ & $5.9 \%$ & $100.0 \%$ \\
\hline & Product purchased & $0.0 \%$ & $19.7 \%$ & $14.3 \%$ & $9.1 \%$ & $16.2 \%$ \\
\hline \multirow{3}{*}{$\begin{array}{l}21-30 \\
\text { years }\end{array}$} & Respondents & 3 & 36 & 17 & 9 & 65 \\
\hline & Age & $4.6 \%$ & $55.4 \%$ & $26.2 \%$ & $13.8 \%$ & $100.0 \%$ \\
\hline & Product purchased & $60.0 \%$ & $59.0 \%$ & $60.7 \%$ & $81.8 \%$ & $61.9 \%$ \\
\hline \multirow{3}{*}{$\begin{array}{l}31-40 \\
\text { years }\end{array}$} & Respondents & 1 & 11 & 6 & 1 & 19 \\
\hline & Age & $5.3 \%$ & $57.9 \%$ & $31.6 \%$ & $5.3 \%$ & $100.0 \%$ \\
\hline & Product purchased & $20.0 \%$ & $18.0 \%$ & $21.4 \%$ & $9.1 \%$ & $18.1 \%$ \\
\hline \multirow{3}{*}{$\begin{array}{l}\text { Above } 40 \\
\text { years }\end{array}$} & Respondents & 1 & 2 & 1 & 0 & 4 \\
\hline & Age & $25.0 \%$ & $50.0 \%$ & $25.0 \%$ & $0.0 \%$ & $100.0 \%$ \\
\hline & Product purchased & $20.0 \%$ & $3.3 \%$ & $3.6 \%$ & $0.0 \%$ & $3.8 \%$ \\
\hline \multirow{3}{*}{ Total } & Respondents & 5 & 61 & 28 & 11 & 105 \\
\hline & Age & $4.8 \%$ & $58.1 \%$ & $26.7 \%$ & $10.5 \%$ & $100.0 \%$ \\
\hline & Product purchased & $100.0 \%$ & $100.0 \%$ & $100.0 \%$ & $100.0 \%$ & $100.0 \%$ \\
\hline
\end{tabular}

Source: Primary Data

Table 1 shows the respondents' age and product purchased in the past 6 months. Most of the respondents (58.1 per cent) purchased 1-2 products in the past 6 months. Among them, 59.0 per cent are in the age group of 21-30 years, 19.7 per cent are in the age group of below 20 years, 18.0 per cent in the age group of 31-40 years and 3.3 per cent in the age group of above 40 years. Only a very small number of respondents ( 4.8 per cent) did not purchase any product during the past 6 months.

Table 2: Association between Age and Product purchased in past 6 months

\begin{tabular}{|l|l|l|l|}
\hline Factors & Value & df & Sig. value \\
\hline Pearson Chi-Square & 7.051 & 9 & $0.632^{*}$ \\
\hline Likelihood Ratio & 6.615 & 9 & 0.677 \\
\hline Linear-by-Linear Association & 0.381 & 1 & 0.537 \\
\hline N of Valid Cases & 105 & & \\
\hline
\end{tabular}

*Significant at $5 \%$ level

Table 2 shows the association between age and product purchased in the past 6 months by the respondents. As per the acceptance of null hypothesis $\mathrm{p}=0.632(\mathrm{p}>0.05)$, product purchased in the past 6 months is not significantly associated with the age of respondents. Therefore, age does not influence the products purchased in the past 6 months.

Table 3: Crosstab on Monthly income and Product purchased in past 6 months

\begin{tabular}{|c|c|c|c|c|c|c|}
\hline \multirow{2}{*}{$\begin{array}{l}\text { Monthly } \\
\text { income }\end{array}$} & & \multicolumn{4}{|c|}{ Product purchased in past 6 months } & \multirow{2}{*}{ Total } \\
\hline & & None & 1-2 & $3-5$ & Above 5 & \\
\hline Upto & Respondents & 0 & 11 & 2 & 1 & 14 \\
\hline Rs.5,000 & Monthly income & $0.0 \%$ & $78.6 \%$ & $14.3 \%$ & $7.1 \%$ & $100.0 \%$ \\
\hline
\end{tabular}




\begin{tabular}{|l|l|l|l|l|l|l|}
\hline & Product purchased & $0.0 \%$ & $18.0 \%$ & $7.1 \%$ & $9.1 \%$ & $13.3 \%$ \\
\hline \multirow{3}{*}{$\begin{array}{l}\text { Rs.5,001 to } \\
\text { Rs.10,000 }\end{array}$} & Respondents & 1 & 16 & 6 & 2 & 25 \\
\cline { 2 - 7 } & Monthly income & $4.0 \%$ & $64.0 \%$ & $24.0 \%$ & $8.0 \%$ & $100.0 \%$ \\
\cline { 2 - 7 } & Product purchased & $20.0 \%$ & $26.2 \%$ & $21.4 \%$ & $18.2 \%$ & $23.8 \%$ \\
\hline \multirow{3}{*}{$\begin{array}{l}\text { Rs.10,001 to } \\
\text { Rs. } 15,000\end{array}$} & Respondents & 3 & 13 & 8 & 0 & 24 \\
\cline { 2 - 7 } & Monthly income & $12.5 \%$ & $54.2 \%$ & $33.3 \%$ & $0.0 \%$ & $100.0 \%$ \\
\cline { 2 - 7 } & Product purchased & $60.0 \%$ & $21.3 \%$ & $28.6 \%$ & $0.0 \%$ & $22.9 \%$ \\
\hline \multirow{3}{*}{$\begin{array}{l}\text { Above } \\
\text { Rs.15,000 }\end{array}$} & Respondents & 1 & 21 & 12 & 8 & 42 \\
\cline { 2 - 7 } & Monthly income & $2.4 \%$ & $50.0 \%$ & $28.6 \%$ & $19.0 \%$ & $100.0 \%$ \\
\cline { 2 - 7 } & Product purchased & $20.0 \%$ & $34.4 \%$ & $42.9 \%$ & $72.7 \%$ & $40.0 \%$ \\
\cline { 2 - 7 } Total & Respondents & 5 & 61 & 28 & 11 & 105 \\
\cline { 2 - 7 } & Monthly income & $4.8 \%$ & $58.1 \%$ & $26.7 \%$ & $10.5 \%$ & $100.0 \%$ \\
\cline { 2 - 7 } & Product purchased & $100.0 \%$ & $100.0 \%$ & $100.0 \%$ & $100.0 \%$ & $100.0 \%$ \\
\hline
\end{tabular}

Source: Primary Data

Table 3 shows the respondents' monthly income and product purchased in the past 6 months. Most of the respondents (58.1 per cent) purchased 1-2 products in the past 6 months. Among them, 34.4 per cent are in the income group of above Rs.15,000, 26.2 per cent are in the income group of Rs.5,001 to Rs.10,000, 21.3 per cent in the income group of Rs.10,001 to Rs.15,000 and 18.0 per cent in the income group of upto Rs.5,000. Only a very small number of respondents (4.8 per cent) did not purchase any product during the past 6 months.

Table 4: Association between Income and Product purchased in past 6 months

*Significant at $5 \%$ level

\begin{tabular}{|l|l|l|c|}
\hline Factors & Value & df & Sig. value \\
\hline Pearson Chi-Square & 12.996 & 9 & $0.163^{*}$ \\
\hline Likelihood Ratio & 14.858 & 9 & 0.095 \\
\hline Linear-by-Linear Association & 3.202 & 1 & 0.074 \\
\hline N of Valid Cases & 105 & & \\
\hline
\end{tabular}

Table 4 shows the association between monthly income and product purchased in the past 6 months by the respondents. As per the acceptance of null hypothesis $p=0.163$ ( $p>0.05)$, product purchased in the past 6 months is not significantly associated with the monthly income of respondents. Therefore, monthly income does not influence the product purchased in the past 6 months by them through online shopping.

Table 5: Rank test on products purchased online

Source: Primary Data

\begin{tabular}{|l|l|l|}
\hline Products & Mean Rank & Rank \\
\hline Books & 4.14 & IV \\
\hline Clothes & 3.39 & III \\
\hline Cosmetics & 4.35 & VI \\
\hline Mobile & 3.25 & I \\
\hline Camera & 4.34 & V \\
\hline Computer & 5.27 & VII \\
\hline Electronics products & 3.26 & II \\
\hline
\end{tabular}


From the above table 5, it is inferred that Mobile gets the first place with the score value (3.25), followed by Electronics products in the second place with the score value (3.26), Clothes in the third place (3.39), Books in the fourth place (4.14), Camera in the fifth place (4.34), Cosmetics in the sixth place (4.35) and Computer in the seventh place (5.27). Therefore it is concluded that, most of the respondents prefer to purchase mobile phones through online shopping.

Table 6: Regression on the Price of the product purchased online and its Availability, Advertisement, No transportation and No hidden charges

\begin{tabular}{|c|c|c|c|c|c|}
\hline \multirow{2}{*}{ Model } & \multicolumn{2}{|c|}{$\begin{array}{l}\text { Unstandardized } \\
\text { Coefficients }\end{array}$} & \multirow{2}{*}{$\begin{array}{l}\begin{array}{l}\text { Standardized } \\
\text { Coefficients }\end{array} \\
\text { Beta }\end{array}$} & \multirow{2}{*}{ t value } & \multirow{2}{*}{ Sig. value } \\
\hline & B & $\begin{array}{l}\text { Std. } \\
\text { Error }\end{array}$ & & & \\
\hline (Constant) & 1.425 & .553 & & 2.578 & $0.011 *$ \\
\hline Availability & .247 & .103 & 0.222 & 2.390 & $0.019 *$ \\
\hline Advertisement & .066 & .081 & 0.077 & .810 & $0.420 *$ \\
\hline No transportation & .094 & .088 & 0.102 & 1.073 & $0.286^{*}$ \\
\hline No hidden charges & .255 & .072 & 0.329 & 3.531 & $0.001 *$ \\
\hline \multicolumn{6}{|c|}{ Dependent Variable : Price } \\
\hline \multicolumn{6}{|c|}{ Independent Variables : Availability, Advertisement, No transportation, No hidden charges } \\
\hline \multicolumn{6}{|l|}{ Multiple R } \\
\hline $\mathrm{R}$ square & \multicolumn{5}{|c|}{$: 0.226$} \\
\hline Adjusted R square & \multicolumn{5}{|c|}{$: 0.195$} \\
\hline F statistics $(4,100)$ & \multicolumn{5}{|c|}{$: 7.280$} \\
\hline
\end{tabular}

*Significant at $5 \%$ level

Table 6 assesses the ability of four control measures (Availability, Advertisement,

No transportation and No hidden charges) to predict levels of reliability on the Price of products ordered online using multiple regression.

$\mathrm{R}$ square value (0.226) indicates the amount of variability explained by the independent variables for 22.6 per cent of variance in the dependent variable and the remaining 77.4 per cent is by some other unknown variable and the problem is not taken into account. The value of $\mathrm{F}(4,100)=$ 7.280 and $\mathrm{p}=0.000(\mathrm{p}<0.05)$ indicates that the model is statistically significant at 5 per cent level and ensures the regression fit.

$\mathrm{p}=0.011(\mathrm{p}<0.05)$ shows that there is a statistically significant difference between the variables and this indicates all the independent variables (Availability, Advertisement, No transportation and No hidden charges) have influence on the Price of the product ordered online. Therefore, the price of the product purchased online depends on its availability, advertisement, transportation charges and hidden charges.

Table 7: Kruskal Wallis Test- Age and Products order online

\begin{tabular}{|l|l|l|l|l|l|}
\hline Products & Age & N & Mean Rank & $\begin{array}{l}\text { Chi square } \\
\text { Value }\end{array}$ & Sig. value \\
\hline Books & Below 20 years & 17 & 55.59 & 3.195 & $0.362 *$ \\
\hline
\end{tabular}




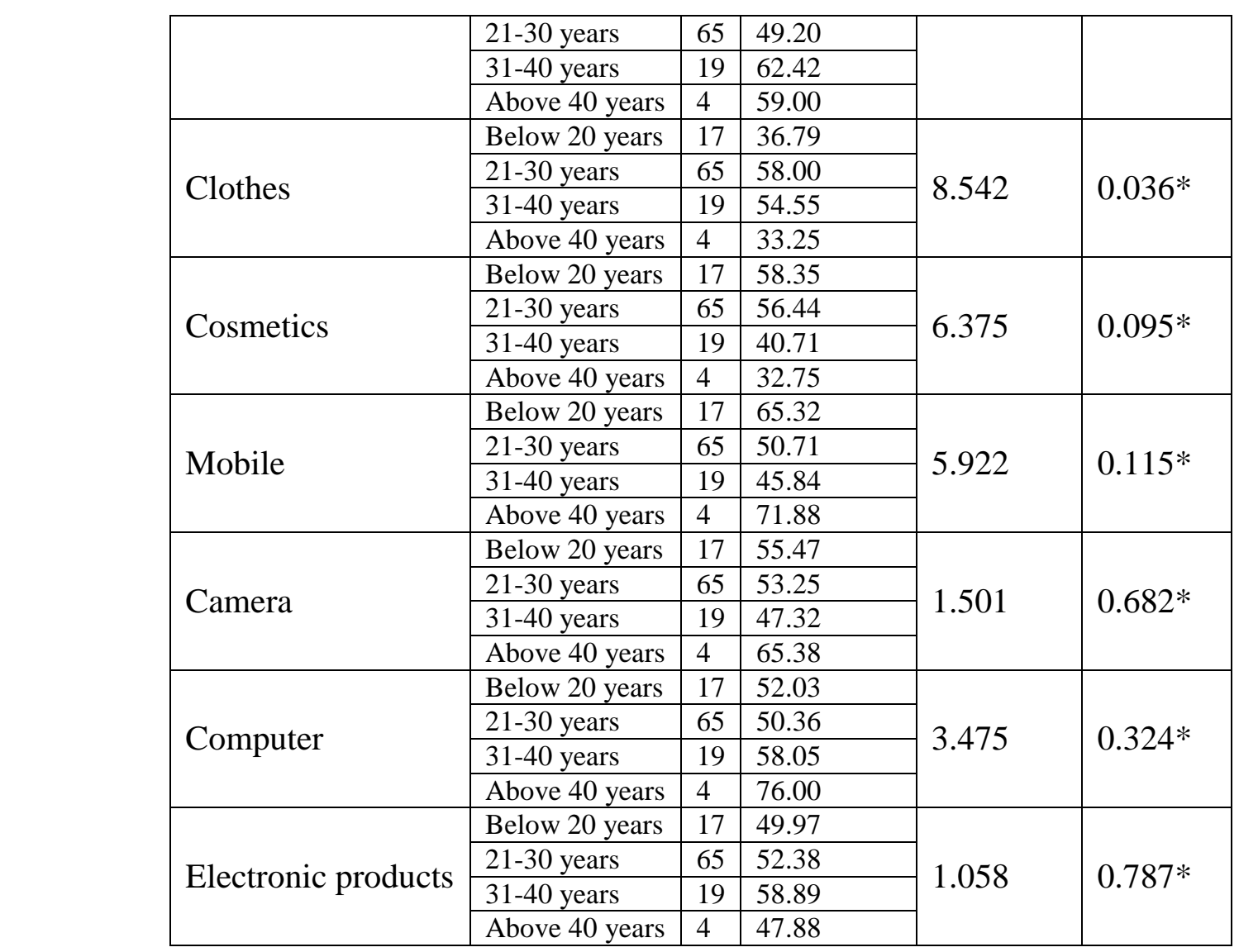

*Significant at $5 \%$ level

Table 7 shows the Kruskal-Wallis test indicating the effect of age on products ordered online. As per the acceptance of null hypothesis $(p>0.05)$, the variables of Books, Cosmetics, Mobile, Camera, Computer and Electronic products with the $\mathrm{p}$ values of $0.362,0.095,0.115,0.682,0.324$ and 0.787 respectively is not influenced by the age of the respondents ordering the products online. Hence it is concluded that age does not affect the all the above variables of the range of products ordered online by the consumers.

As per rejection of null hypothesis $(\mathrm{p}<0.05)$, the variable Clothes with the $\mathrm{p}$ value of 0.036 is influenced by the age of the consumers ordering goods online. Hence it is concluded that Clothes are ordered online by the customers online irrespective of their age.

\section{FINDINGS OF THE STUDY}

- Majority of the consumers purchased 1 to 2 products in the past 6 months through online shopping. Most of the consumers surveyed in this study purchasing goods online use computer for 1-3 years.

- In the present study, 74 per cent of the consumers prefer cash payment, 18 per cent of the consumers prefer debit card payment, and remaining 8 per cent of the consumers prefer credit card payment. Therefore, majority of the consumers purchasing goods online prefer cash payment as they feel it is less risky to avoid cyber-crimes. 
- The study shows that 49.5 per cent of the consumers rate online shopping as good, 26.7 per cent of the consumers rate adequate, 21.9 per cent of the consumers rate excellent and remaining 1.9 per cent of the consumers rate unacceptable. Therefore, majority of consumers purchasing goods online rate the overall quality as good.

- Age and monthly income do not influence the products purchased in the past 6 months. The consumers purchasing goods online belong to different age and income groups. They prefer online shopping as they consider it easy and convenient.

- Mobile gets the first place followed by Electronics products, Clothes, Books, Camera, Cosmetics and Computer in the goods purchased by consumers online. Most of the respondents prefer to purchase mobile phones through online shopping. Clothes are ordered online by the customers online irrespective of their age.

- Price of the product purchased online depends on its availability on the online shopping portal, advertisement charges of that particular product, its transportation charges through shipping or other modes and other hidden charges.

\section{SUGGESTIONS AND CONCLUSION}

From the consumers' perspective, there are many advantages of online shopping as it is more convenient for shopping on the internet and there is no crowd of people when shopping through online. They can purchase their products without any difficulty with a click on their mouse. Ecommerce is becoming an important trend in this modern information technology society. Customers should be more aware about the cyber-crimes as all positive aspects have negatives too.

Consumers' socio-demographic, pattern of buying online and purchase perception has been studied in this survey which concludes that the age and monthly income does not affect the attitude of consumers in buying goods online. The price of the product purchased online depends on various factors and consumers should be cautious while choosing them. They should purchase every product based on the reviews given by other previous buyers. People from different age groups do online shopping regularly. The attitude of consumers changes with time. However, consumers find online shopping very comfortable because of many options like cash on delivery, customization or personalization of the websites, home delivery and free shipping charges for certain products.

\section{REFERENCES}

[1] AnupamaSundar.D., (2016). Internet Shopping: Factors Influencing Students Buying Intention Online. International Journal of Research in Commerce \& Management, June 2016, Vol. 7, No. 6, pp. 47-55.

[2] Ashish Bhatt, (2014). Consumer Attitude towards Online Shopping in Selected Regions of Gujarat. Journal of Marketing Management, June 2014, Vol. 2, No. 2, pp. 29-56.

[3] Divya, S., \& Regi, B. (2014). An Empirical study on effectiveness of Social Media as a Marketing tool. International Journal of current research and academic review.

[4] Franco, C. E., \& Regi, S. B. (2016). ADVANTAGES AND CHALLENGES OF ECOMMERCE CUSTOMERS AND BUSINESSES: IN INDIAN 
PERSPECTIVE. International Journal of Research -GRANTHAALAYAH A Knowledge Repository, 4(3), 7-13.

[5] Golden, S. A. R., \& Regi, S. B. Mobile Commerce in Modern Business Era.

[6] Golden, S. A. R., Regi, S. B., \& Franco, C. E. (2014). A study on Impact of Information Technology (IT) in Modern Banking Sector. Golden Research Thoughts, 3(11), 1-4.

[7] Hemamalini K., (2013). Influence of Product Types on Consumer's Attitude towards Online Shopping: An Empirical Study in the Indian Context. International Journal of Marketing Studies, Vol. 5, No. 5; 2013.

[8] Jahng, J., Jain, H., and Ramamurthy, K., (2001). The impact of electronic commerce environment on user behavior. E-service Journal (1:1), pp. 41-53.

[9] Regi, S. B., \& Golden, S. A. R. (2014). A Descriptive Study On The Role Of Consumer Psychology And Behaviour In Product Purchasing. Indian Streams Research Journal, 3(12), 1-6.

[10] Regi, S. B., \& Golden, S. A. R. (2014). A Study On Attitude Of Employee Towards Working Environment With Special Reference To RR Pvt Ltd.Review Of Research, 2(2), 1-5.

[11] Regi, S. B., Golden, S. A. R., \& Franco, C. E. (2014). EMPLOYEE PERCEPTION TOWARDS EFFECTIVENESS OF HR PRACTICES IN PUBLIC SECTOR BANKS IN TIRUNELVELI DISTRICT. Tactful Management Research Journal, 2(6), 1-4.

[12] Regi, S. B., Golden, S. A. R., \& Franco, C. E. (2014). Reforms In Insurance Sector In India- A Empirical Study. Review Of Research, 3(9), 1-5.

[13] Regi, S. B., Golden, S. A. R., \& Franco, C. E. (2014). ROLE OF COMMERCIAL BANK IN THE GROWTH OF MICRO AND SMALL ENTERPRISES. Golden Research Thoughts, 3(7), 1-5.

[14] Regi, S. B., Golden, S. A. R., \& Franco, C. E. (2014). SELF EMPLOYMENT AS SUSTAINABLE EMPLOYMENT"- A STUDY ON SELF EMPLOYED WOMEN'S ASSOCIATION (SEWA) GUJARAT, INDIA. Indian Streams Research Journal, 4(2), 1-5.

[15] Saad Akbar and Paul TJ James Bangkok University. Thailand Consumers' attitude towards online shopping Factors influencing employees of crazy domains to shop online. Journal of Management and Marketing Research, pp:01. 